Published in final edited form as:

J Am Chem Soc. 2019 September 04; 141(35): 13778-13782. doi:10.1021/jacs.9b07512.

\title{
Total Synthesis and Structural Validation of Phosdiecin A via Asymmetric Alcohol-Mediated Carbonyl Reductive Coupling
}

\author{
Franco Della-Felice $\$, \dagger$, Ariel M. Sarotti ${ }^{\prime \prime}$, Michael J. Krische ${ }^{*}, \dagger$, Ronaldo A. Pilli ${ }^{*} \S$ \\ $\S$ Institute of Chemistry, University of Campinas (UNICAMP), P.O. Box 6154, CEP 13083-970 \\ Campinas, São Paulo, Brazil \\ tDepartment of Chemistry, University of Texas at Austin, Austin, Texas 78712, United States \\ "Instituto de Química Rosario, Facultad de Ciencias Bioquímicas y Farmacéuticas, Universidad \\ Nacional de Rosario-CONICET, Suipacha 531, S2002LRK Rosario, Argentina
}

\begin{abstract}
The first total synthesis and structural validation of phosdiecin A was accomplished in 13 steps (LLS) through asymmetric iridium-catalyzed alcohol-mediated carbonyl reductive coupling. The present route is the shortest among $>30$ total and formal syntheses of fostriecin family members.
\end{abstract}

\section{Graphical Abstract}

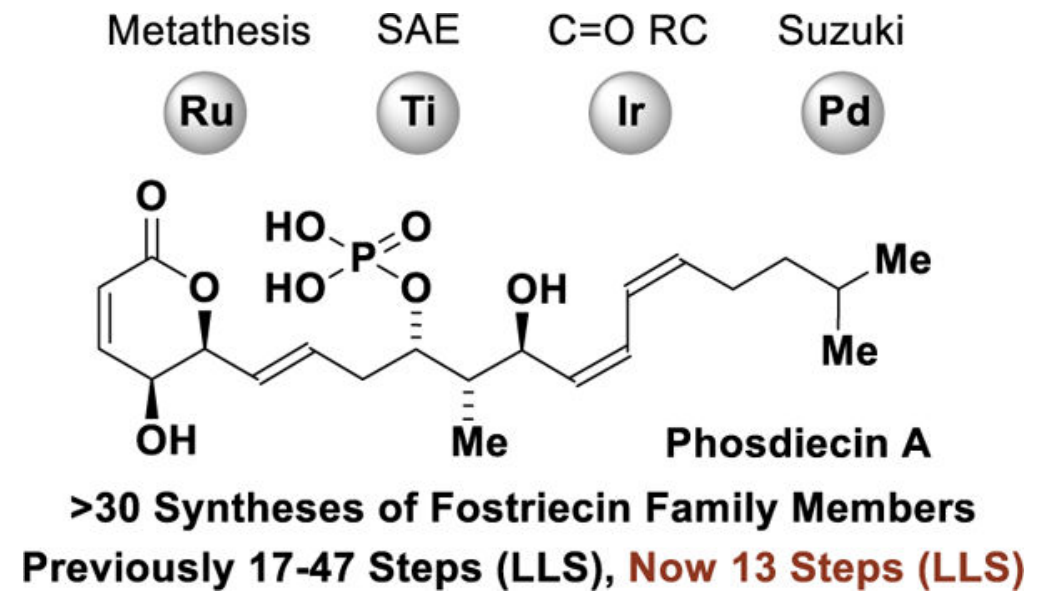

Fostriecin (CI-920), a metabolite produced by Streptomyces pulveraceus isolated from a Brazilian soil sample in $1983,{ }^{1}$ is the forerunner to a ever-growing family of phosphorylated polyketide natural products that modulate signal transduction pathways in mammalian cells, including the regulation of tumor microenvironment functions that support tumor development and protect cancer cells from chemotherapeutic stress. ${ }^{2}$ These properties are linked to their protein phosphatase inhibitory action, in particular, the serine/threonine

\footnotetext{
*Corresponding Authors. mkrische@mail.utexas.edu, pilli@iqm.unicamp.br.

Supporting Information Available: Experimental procedures and spectral data for all new compounds. This material is available free of charge via the internet at http://pubs.acs.org.

The authors declare no competing financial interest.
} 
phosphatases PP1 and PP2A, which display functional roles that include cell cycle regulation (PP1 and PP2A), RNA splicing (PP1), cell differentiation (PP2A), apoptosis (PP2A), among others. ${ }^{2}$ Phase I clinical trials were launched for fostriecin but were halted before the maximum tolerated dose was established, as its instability and unpredictable purity limited supply. ${ }^{3}$ In 1992, Ohkuma and coworkers reported the isolation of a metabolite, dubbed sultriecin, from $S$. roseiscleroticus No. L827-7 from an Indian soil sample bearing a related hydroxylated dihydropyranone and a $(Z, Z, E)$-triene linked by an anti-1,3-diol tether, which was proposed to incorporate a sulfate moiety at C-9. ${ }^{4}$ In 2010, Boger and coworkers reassigned the structure as the C-9 sodium phosphate monoester and established its relative and absolute configuration, renaming it phostriecin. ${ }^{5}$ Like fostriecin, phostriecin has garnered interest as a potential chemotherapeutic agent due to its potent and selective inhibition of protein phosphatase $2 \mathrm{~A}$ (PP2A) ${ }^{2,5}$ More recently, Thomasi and coworkers isolated two new phosphorylated polyketides, phosdiecins A and B, from the fermentation broth of Streptomyces sp. SS99BA-2 collected on the Brazilian coast. ${ }^{6}$ The structural assignment of phosdiecins A and B (including absolute stereochemistry) has not been corroborated by total synthesis and the biological properties of these compounds remain unexplored.

The prospect of developing chemotherapeutic agents based on serine/threonine protein phosphatase inhibition has driven efforts toward the de novo chemical synthesis of fostriecin and related phosphorylated polyketide natural products (Figure 1). ${ }^{7}$ To date, over 30 total and formal syntheses of "fostriecin family" members have been reported. ${ }^{7}$ The reported syntheses of these compounds range between 17-47 steps (LLS) in length. While their complexity is variable and earlier syntheses emphasized structure elucidation, it is clear that the challenges posed by this compound class are not fully resolved. Recently, one of the present authors developed a set of carbonyl reductive couplings and related hydrogen autotransfer processes that directly convert lower alcohols to higher alcohols. ${ }^{8}$ The redoxeconomy of these processes has been shown to contribute to increased efficiency in polyketide construction. ${ }^{9}$ Given the longstanding challenges posed by the synthesis of the fostriecin family of natural products, and to further benchmark the utility of our catalytic methods, a campaign toward phosdiecin A was undertaken. Here, we disclose a 13 step (LLS) total synthesis of phosdiecin A - the shortest among >30 syntheses of fostriecin family members.

Due to uncertainty regarding the structural assignment of phosdiecins A and $\mathrm{B}$, as a prelude to our experimental work DP4+ calculations were undertaken to assess the veracity of the proposed structure (see Supporting Information). ${ }^{10}$ In particular, the assignment of relative stereochemistry between the pyran C4-C5 stereotriad with respect to the C9-C11 stereotriad was ambiguous. The computational work validates the relative configuration proposed by Thomasi and coworkers, which emerged from these studies as the most probable stereoisomer. Retrosynthetically, phosdiecin A was envisioned to arise through the convergent assembly of Fragments A, B and $\mathbf{C}$ (Figure 2). Fragment $\mathbf{A}$ was anticipated to be accessible through the Sharpless asymmetric epoxidation (SAE)-kinetic resolution (KR) ${ }^{11}$ of furfural adduct 2 (via Achmatowicz reaction) followed by iridium-catalyzed internal redox isomerization. ${ }^{12}$ Fragment $\mathbf{B}$ shows higher complexity due to the $\mathrm{C} 9-\mathrm{C} 11$ stereotriad. ${ }^{13}$ For 
this fragment, successive use of the present authors carbonyl reductive coupling methodology was employed. ${ }^{14,15}$ Specifically, crotylation of the acetylenic aldehyde $\mathbf{6}^{14}$ followed by allylation of the $\beta, \gamma$-stereogenic alcohol $9^{15}$ was planned. Cross-metathesis of Fragments $\mathbf{A}$ and $\mathbf{B}$, and Suzuki cross-coupling of the resulting vinyl bromide $\mathbf{1 0}$ with Fragment $\mathbf{C}$ would deliver phosdiecin A. Realization of this concise, convergent approach could serve as a prelude to the synthesis of other fostriecin family members, as well as the design of synthetic analogues for structure-activity studies.

Preparation of Fragment $\mathbf{A}$ begins with addition of vinyl magnesium bromide to furfural $\mathbf{1}$ (Scheme 1). The resulting allylic alcohol 2 was subjected to conditions for SAE-KR ${ }^{11}$ to provide the lactol 3 in 41\% yield, 3:1 dr and 92\% ee. Next, to install the C4-C5 syn-diol, an iridium-catalyzed dynamic kinetic internal redox isomerization was performed. ${ }^{12}$ Lactone 4 was obtained in $36 \%$ yield as a single stereoisomer (see Supporting Information for determination of relative and absolute stereochemistry). Protection of the secondary alcohol as the PMB-derivative delivers Fragment $\mathbf{A}$ in a total of four steps (LLS) from furfural $\mathbf{1 .}$

In pursuit of an efficient route to Fragment $\mathbf{B}$, we recently developed the anti-diastereo- and enantioselective crotylation of TIPS-protected acetylenic aldehyde 6 through 2-propanolmediated reductive coupling of a-methyl allyl acetate catalyzed by the iridium-complex $(R)$ Ir-I. ${ }^{14}$ This reaction was conducted on gram-scale without any erosion in yield or stereoselectivity. To convert the homoallylic alcohol 7 to Fragment B, the C11 alcohol was transformed to the PMB ether, the acetylenic TIPS moiety was removed and the resulting terminal alkyne was treated with NBS to form the acetylenic bromide $8 .{ }^{16}$ Selective ozonolytic cleavage of the terminal alkene ${ }^{17}$ followed by diimide reduction ${ }^{18}$ delivered the vinyl bromide 9. Finally, direct iridium-catalyzed allylation of the alcohol 9, ${ }^{15}$ which bypasses discrete generation of the configurationally labile chiral a-stereogenic aldehyde, provide Fragment $\mathbf{B}$ (see Supporting Information for determination of relative and absolute stereochemistry). Here, catalyst-directed diastereoselectivity is amplified by Felkin-Anh selectivity, ${ }^{19}$ guiding assembly of the C9-C11 stereotriad with high levels of control (Scheme 2).

With Fragments A and $\mathbf{B}$ in hand, a challenging cross-metathesis was attempted (Scheme 3). This process required extensive experimentation, as the vinyl bromide moiety poses issues of functional group compatibility. ${ }^{20}$ Additionally, the vinyl-substituted pyrans are prone to competing olefin isomerization. ${ }^{21}$ Ultimately, optimal reaction conditions employing Grubbs $2^{\text {nd }}$ generation catalyst afforded vinyl bromide $\mathbf{1 0}$ in $31 \%$ yield. Suzuki-Miyaura crosscoupling with Fragment $\mathbf{C}^{22}$ was conducted using McDonald's protocol. ${ }^{23}$ The reaction byproducts were most easily removed by subjecting the crude $(Z, Z)$-diene 11 to $1 \mathrm{H}$ tetrazole-promoted phosphorylation conditions using diallyl $\mathrm{N}, \mathrm{N}$ diisopropylphosphoramidite followed by peroxide-mediated oxidation to provide the protected phosphate ester $\mathbf{1 2}$ in 56\% yield over the two steps. ${ }^{24}$ Removal of the PMB protecting group followed by palladium-catalyzed allylic reductive cleavage of the diallyl phosphate ester $\mathbf{1 2}^{25}$ provided (+)-phosdiecin A as the sodium salt. A work up procedure involving treatment with Dowex-50 provided the protonated material. The spectral data $\left({ }^{1} \mathrm{H}\right.$ 
and ${ }^{13} \mathrm{C}$ NMR) were virtually identical to natural phosdiecin A (see Supporting Information).

In summary, the first total synthesis of phosdiecin A was accomplished in 13 steps (LLS) through asymmetric iridium-catalyzed alcohol-mediated carbonyl reductive coupling. In >30 total and formal syntheses of structurally related natural products, 17-47 steps (LLS) were required. This work validates the initial structure proposed by Thomasi for this natural product. ${ }^{6}$ Most importantly, the methods and strategies utilized in the present synthesis should be transferrable to other fostriecin family members and functional analogues. Studies toward this end are in progress and will be reported in due course.

\section{Supplementary Material}

Refer to Web version on PubMed Central for supplementary material.

\section{Acknowledgments.}

The Robert A. Welch Foundation (F-0038), and the NIH-NIGMS (R01 GM093905, 1 S10 OD021508-01) are acknowledged for financial support. Fundação de Amparo aà Pesquisa do Estado de São Paulo (FAPESP) is acknowledged for a research internship scholarship support (F.D.F. 2017/18487-4) and for research grants (2013/07607-8, 2014/25474-8, 2016/12541-4). CONICET is acknowledged for financial support (PIP 11220130100660CO). The authors thank Dr. S. S. Thomasi for NMR data for natural phosdiecin A. RAP is grateful to the academic guidance received from Albert J. Kascheres. RAP, AMS and FDF dedicate to Professor Edmundo A. Rúveda (in memoriam).

\section{REFERENCES}

(1). For isolation of Fostriecin (CI-920), see: Tunac JB; Graham BD; Dobson WE Novel Anti-Tumor Agents CI-920, PD 113,270 and PD 113,271. I. Taxonomy, Fermentation and Biological Properties. J. Antibiot 1983, 36, 1595. [PubMed: 6689323] (b)Stampwala SS; Bunge RH; Hurley TR; Willmer NE; Brankiewicz AJ; Steinman CE; Smitka TA; French JC Novel Antitumor Agents CI-920, PD 113,270 and PD 113,271. II. Isolation and Characterization. J. Antibiot 1983, 36, 1601. [PubMed: 6689324]

(2). (a)For selected reviews encompassing the biological properties of fostriecin and structurally related natural products, see: Lewy DS; Gauss C-M; Soenen DR; Boger DL Fostriecin: Chemistry and Biology. Curr. Med. Chem 2002, 9, 2005. [PubMed: 12369868] (b)McConnell JL; Wadzinski BE Targeting Protein Serine/Threonine Phosphatases for Drug Development Mol. Pharm 2009, 75, 1249.(c)Lazo JS; Wipf P Phosphatases as Targets for Cancer Treatment. Curr. Op. Invest. Drugs 2009, 10, 1297.(d)Kalev P; Sablina AA Protein Phosphatase 2A as a Potential Target for Anticancer Therapy. Anti-Cancer Agents Med. Chem 2011, 11, 38.(e)Janssens V; Rebollo A The Role and Therapeutic Potential of Ser/Thr Phosphatase PP2A in Apoptotic Signaling Networks in Human Cancer Cells. Curr. Mol. Med 2012, 12, 268. [PubMed: 22300139] (f)Zhang M; Yogesha SD; Mayfield JE; Gill GN; Zhang Y Viewing Serine/Threonine Protein Phosphatases through the Eyes of Drug Designers. FEBS J 2013, 280, 4739. [PubMed: 23937612] (g)Ruvolo PP Role of Protein Phosphatases in the Cancer Microenvironment. BBA Mol. Cell Res 2019, 1866, 144.

(3). (a)de Jong RS; Mulder NH; Uges DRA; Sleijfer D. Th.; Höppener FJP; Groen HJM; Willemse PHB; van der Graaf WTA; de Vries EGE Phase I and Pharmacokinetic Study of the Topoisomerase II Catalytic Inhibitor Fostriecin Brit. J. Cancer 1999, 79, 882.(b)Lê LH; Erlichman C; Pillon L; Thiessen JJ; Day A; Wainman N; Eisenhauer EA; Moore MJ Phase I and Pharmacokinetic Study of Fostriecin Given as An Intravenous Bolus Daily for Five Consecutive Days. Invest. New Drugs 2004, 22, 159. [PubMed: 14739664]

(4). Ohkuma H; Naruse N; Nishiyama Y; Tsuno T; Hoshino Y; Sawada Y; Konishi M; Oki T Sultriecin, A New Antifungal and Antitumor Antibiotic from Streptomyces roseiscleroticus: 
Production, Isolation, Structure and Biological Activity J. Antibiot 1992, 45, 1239. [PubMed: 1399844]

(5). (a)Burke CP; Haq N; Boger DL Total Synthesis, Assignment of the Relative and Absolute Stereochemistry, and Structural Reassignment of Phostriecin (aka Sultriecin). J. Am. Chem. Soc 2010, 132, 2157. [PubMed: 20108904] (b)Burke CP; Swingle MR; Honkanen RE; Boger DL Total Synthesis and Evaluation of Phostriecin and Key Structural Analogues. J. Org. Chem 2010, 75, 7505. [PubMed: 20669916]

(6). Thomasi SS; Ladeira C; Ferreira D; Sprenger RF; Badino AC; Ferreira AG; Venâncio T Identification of Two New Phosphorylated Polyketides from a Brazilian Streptomyces sp. Through the Use of LC-SPE/NMR. Helv. Chim. Acta 2016, 99, 281.

(7). Trost BM; Knopf JD; Brindle CS Synthetic Strategies Employed for the Construction of Fostriecin and Related Natural Products. Chem. Rev 2016, 116, 15035. [PubMed: 28027648]

(8). (a)For recent reviews on alcohol-mediated carbonyl reductive coupling, see: Nguyen KD; Park BY; Luong T; Sato H; Garza VJ; Krische MJ Metal Catalyzed Reductive Coupling of OlefinDerived Nucleophiles: Reinventing Carbonyl Addition. Science 2016, 354, 300 (ah5133). (b)Kim SW; Zhang W; Krische MJ Catalytic Enantioselective Carbonyl Allylation and Propargylation via Alcohol Mediated Hydrogen Transfer: Merging the Chemistry of Grignard and Sabatier. Acc. Chem. Res 2017, 50, 2371. [PubMed: 28792731]

(9). (a)For recent reviews on the application of alcohol-mediated carbonyl reductive coupling in targetoriented synthesis, see: Dechert-Schmitt A-MR; Schmitt DC; Gao X; Itoh T; Krische MJ Polyketide Construction via Hydrohydroxyalkylation and Related Alcohol CH Functionalizations: Reinventing the Chemistry of Carbonyl Addition. Nat. Prod. Rep 2014, 31, 504. [PubMed: 24514754] (b)Feng J; Kasun ZA; Krische MJ Enantioselective Alcohol C-H Functionalization for Polyketide Construction: Unlocking Redox-Economy and Site-Selectivity for Ideal Chemical Synthesis. J. Am. Chem. Soc 2016, 138, 5467. [PubMed: 27113543] (c)Schwartz LA; Krische MJ Hydrogen-Mediated C-C Bond Formation: Stereo- and SiteSelective Chemical Synthesis Beyond Stoichiometric Organometallic Reagents. Isr. J. Chem 2018, 58, 45.

(10). (a)Grimblat N; Zanardi MM; Sarotti AM Beyond DP4: An Improved Probability for the Stereochemical Assignment of Isomeric Compounds using Quantum Chemical Calculations of NMR Shifts. J. Org. Chem 2015, 80, 12526. [PubMed: 26580165] (b)Grimblat N; Sarotti AM Computational Chemistry to the Rescue: Modern Toolboxes for the Assignment of Complex Molecules by GIAO NMR Calculations. Chem. Eur. J 2016, 22, 12246. [PubMed: 27405775] (c)Grimblat N; Gavin JA; Hernández Daranas A; Sarotti AM Combining the Power of J Coupling and DP4 Analysis on Stereochemical Assignments: The J-DP4 Methods. Org. Lett 2019, 21 , 4003. [PubMed: 31124687]

(11). (a)Kobayashi Y; Kusakabe M; Kitano Y; Sato F Preparation of Optically Active 2-Furylcarbinols by Kinetic Resolution Using the Sharpless Reagent. J. Org. Chem 1988, 53, 1586.(b)Kusakabe M; Kitano Y; Kobayashi Y; Sato F Preparation of Optically Active 2-Furylcarbinols by Kinetic Resolution Using The Sharpless Reagent and Their Application in Organic Synthesis. J. Org. Chem 1989, 54, 2085.(c)Kametani T; Tsubuki M; Tatsuzaki Y; Honda T Synthesis of Optically Active 2-Furylmethanols as Useful Chiral Building Blocks and Its Application to The Synthesis of (5R,6S)-6-Acetoxyhexadecan-5-olide and (+)-Disparlure. J. Chem. Soc. Perkin Trans. 1 1990, 639.

(12). Wang H-Y; Yang K; Bennett SR; Guo S; Tang W Iridium-Catalyzed Dynamic Kinetic Isomerization: Expedient Synthesis of Carbohydrates from Achmatowicz Rearrangement Products. Angew. Chem. Int. Ed 2015, 54, 8756.

(13). For a review of polyketide stereotetrads in natural products, see: Koskinen AMP; Karisalmi K Polyketide Stereotetrads in Natural Products. Chem. Soc. Rev 2005, 34, 677. [PubMed: 16186897]

(14). Brito GA; Della-Felice F; Luo G; Burns AS; Pilli R; Rychnovsky SD; Krische MJ Catalytic Enantioselective Allylations of Acetylenic Aldehydes via 2-Propanol-Mediated Reductive Coupling. Org. Lett 2018, 20, 4144. [PubMed: 29938513]

(15). (a)Schmitt DC; Dechert-Schmitt A-MR; Krische MJ Iridium-Catalyzed Allylation of Chiral $\beta$ Stereogenic Alcohols: Bypassing Discrete Formation of Epimerizable Aldehydes. Org. Lett 2012, 
14, 6302. [PubMed: 23231774] (b)Dechert-Schmitt A-MR; Schmitt DC; Krische MJ Protectinggroup-Free Diastereoselective C-C Coupling of 1,3-Glycols and Allyl Acetate through SiteSelective Primary Alcohol Dehydrogenation. Angew. Chem. Int. Ed 2013, 52, 3195.

(16). Li M; Li Y; Zhao B; Liang F; Jin L-Y Facile and Efficient Synthesis of 1-Haloalkynes via DBUMediated Reaction of Terminal Alkynes and N-Haloimides under Mild Conditions. RSC Adv 2014, 4, 30046.

(17). Veysoglu T; Mitscher LA; Swayze JK A Convenient Method for the Control of Selective Ozonizations of Olefins. Synthesis 1980, 807.

(18). (a)Dewey RS; van Tamelen EE Reduction of Isolated Olefinic Bonds by Means of pToluenesulfonylhydrazide. J. Am. Chem. Soc 1961, 83, 3729.(b)Myers AM; Zheng B; Movassaghi M Preparation of the Reagent o-Nitrobenzenesulfonylhydrazide. J. Org. Chem 1997, 62, 7507. [PubMed: 11671877]

(19). Mengel A; Reiser O Around and beyond Cram's Rule. Chem. Rev 1999, 99, 1191. [PubMed: 11749444]

(20). (a)Macnaughtan ML; Johnson MJA; Kampf JW Olefin Metathesis Reactions with Vinyl Halides: Formation, Observation, Interception, and Fate of the Ruthenium-Monohalomethylidene Moiety. J. Am. Chem. Soc 2007, 129, 7708. [PubMed: 17542588] (b)Macnaughtan ML; Gary J,B; Gerlach DL; Johnson MJA; Kampf JW Cross-Metathesis of Vinyl Halides. Scope and Limitations of Ruthenium-Based Catalysts. Organometallics 2009, 28, 2880.

(21). (a)Wang G; Krische MJ Total Synthesis of (+)-SCH 351448 via Transfer Hydrogenative C-C Coupling: Efficiency via Chemoselectivity and Redox-Economy Powered by Metal Catalysis. J. Am. Chem. Soc 2016, 138, 8088. [PubMed: 27337561] (b)Shin I; Hong S; Krische MJ Total Synthesis of Swinholide A: An Exposition in Hydrogen-Mediated C-C Bond Formation. J. Am. Chem. Soc 2016, 138, 14246. [PubMed: 27779393]

(22). Fragment $\mathrm{C}$ was prepared via rhodium-catalyzed hydroboration of the corresponding alkyne: Ohmura T; Yamamoto Y; Miyaura N Rhodium- or Iridium-Catalyzed trans-Hydroboration of Terminal Alkynes, Giving (Z)-1-Alkenylboron Compounds. J. Am. Chem. Soc 2000, 122, 4990.

(23). Robles O; McDonald FE Convergent Synthesis of Fostriecin via Selective Alkene Couplings and Regioselective Asymmetric Dihydroxylation. Org. Lett 2009, 11, 5498. [PubMed: 19902969]

(24). (a)Bannwarth W; Trzeciak AA Simple and Effective Chemical Phosphorylation Procedure for Biomolecules. Helv. Chim. Acta 1987, 70, 175.(b)Bannwarth W; Küng E Bis(Allyloxy) (diisopropylamino)phosphine as a New Phosphinylation Reagent for the Phosphorylation of Hydroxy Functions. Tetrahedron Lett 1989, 30, 4219.(c) Wang YG; Takayama R; Kobayashi Y Total Synthesis of Phoslactomycin B and its Biosynthetic Deamino Precursor. Angew. Chem. Int. Ed 2006, 45, 3320.

(25). (a)Hayakawa Y; Kato H; Uchiyama M; Kajino H; Noyori R Allyloxycarbonyl Group: A Versatile Blocking Group for Nucleotide Synthesis. J. Org. Chem 1986, 51, 2400;(b)Miyashita K; Ikejiri M; Kawasaki H; Maemura S; Imanishi T Total Synthesis of an Antitumor Antibiotic, Fostriecin (CI-920). J. Am. Chem. Soc 2003, 125, 8238; [PubMed: 12837094] (c)Shibahara S; Fujino M; Yasumasa T; Okamoto N; Esumi T; Takahashi K; Ishihara J; Hatakeyama S Total Synthesis of (+)-Fostriecin and (+)-Phoslactomycin B. Synthesis 2009, 17, 2935. 

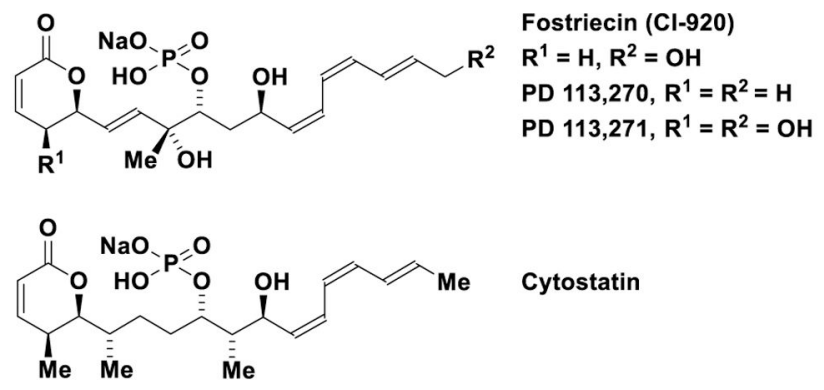

Cytostatin

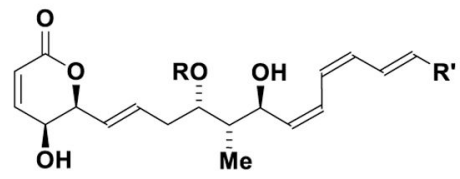

Phostriecin

$\mathrm{R}=\mathrm{PO}_{3} \mathrm{HNa}, \mathrm{R}^{\prime}=n-\mathrm{C}_{5} \mathrm{H}_{11}$ (Misassigned as Sultriecin $\mathbf{R}=\mathrm{SO}_{3} \mathrm{Na}, \mathbf{R}^{\prime}=n-\mathrm{C}_{5} \mathrm{H}_{11}$ )

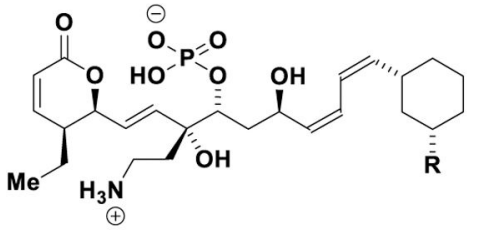

Phoslactomycin A, R = OCO'Pr

Phoslactomycin B, R = H

Leustroducsin $\mathrm{H}, \mathbf{R}=\mathrm{OH}$

Leustroducsin $B, \mathbf{R}=$
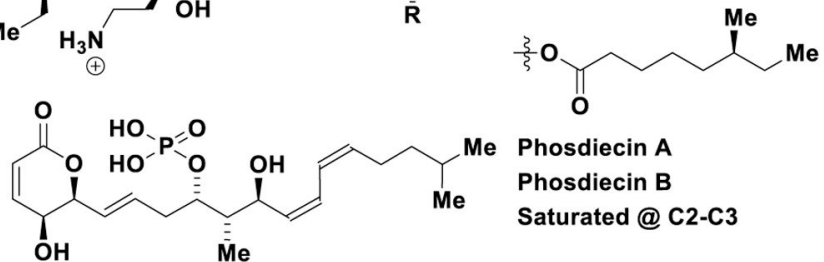

>30 TOTAL and FORMAL SYNTHESES

Fostriecin: 15 Prior Syntheses, 19-34 Steps (LLS)

PD 113.271: 1 Prior Synthesis, 27 Steps (LLS)

Phostriecin: 1 Prior Synthesis, 25 Steps (LLS)

Cvtostatin: 5 Prior Syntheses, 21-27 Steps (LLS)

Phoslactomvcin A: 1 Prior Synthesis, 34 Steps (LLS)

Phoslactomycin B : 5 Prior Syntheses, 29-40 Steps (LLS)

Leustroducsin BB: 6 Prior Syntheses, 17-47 Steps (LLS)

Phosdiecin A: 13 steps (LLS)

Figure 1.

Total synthesis of fostriecin and related phosphorylated polyketide natural products. LLS = Longest linear sequence. See Supporting Information and ref. 7 for literature references pertaining to the syntheses of the indicated compounds, graphical summaries of their syntheses and a detailed inventory of step count. 
<smiles>[R]/C=C\C=C/[C@@H](O)[C@H](C)[C@H](C/C=C/[C@H]1OC(=O)C=C[C@@H]1O)OP(=O)(O)O</smiles>

Phosdiecin A

( $R$ = isoamyl)<smiles>CP=B/C=C\CCC(C)C</smiles>

Fragment $\mathrm{C}$

Pd

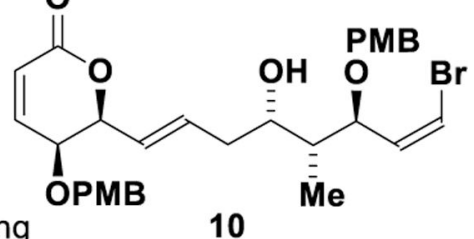

Suzuki X-Coupling

Ti<smiles>C=CC(O)c1ccco1</smiles>

SAE Kinetic Resolution

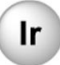

Redox

2 Isomerization

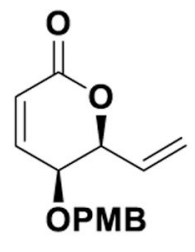

Fragment A

4 Steps (LLS)
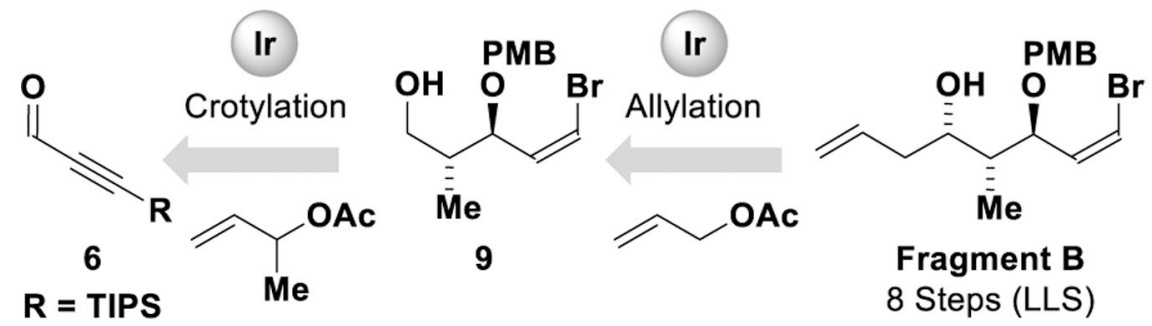

Figure 2.

Retrosynthetic analysis of phosdiecin A. 

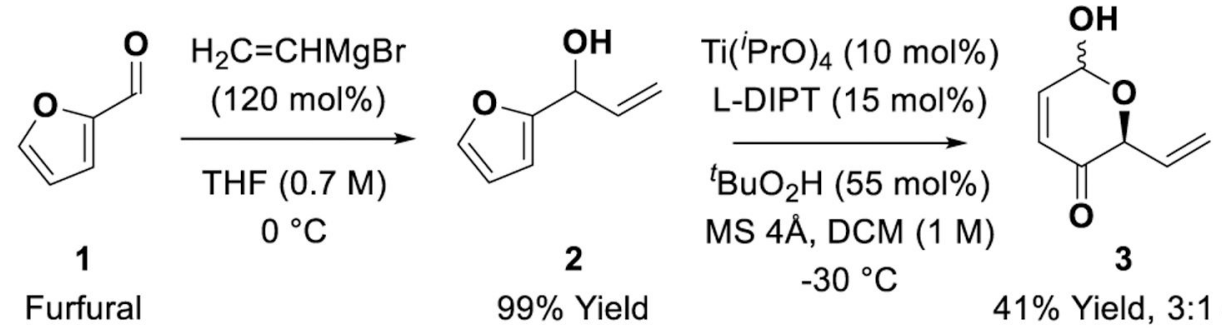

Furfural

$99 \%$ Yield

$[\mathrm{Ir}(\operatorname{cod}) \mathrm{Cl}]_{2}(2.5 \mathrm{~mol} \%)$ 2,6-( $\left.\mathrm{CF}_{3}\right)_{2}-\mathrm{BzOH}(20 \mathrm{~mol} \%)$

DCE (0.5 M)

$25^{\circ} \mathrm{C}$<smiles>C=CC1OC(=O)C=CC1O</smiles>

4

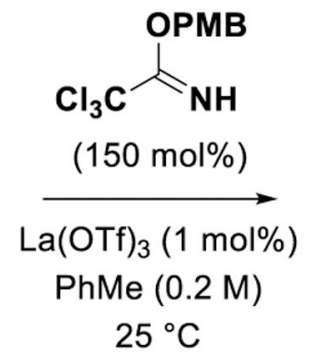

$36 \%$ Yield, $>20: 1 \mathrm{dr}$
$41 \%$ Yield, 3:1 dr $92 \%$ ee<smiles>C=C[C@H]1OC(=O)C=C[C@@H]1OC(C)(C)C</smiles>

Fragment A

95\% Yield

Scheme 1.

Preparation of Fragment A. ${ }^{a}$

aYields are of material isolated by silica gel chromatography. Diastereoselectivities were determined by ${ }^{1} \mathrm{H}$ NMR of crude reaction mixtures. Enantioselectivities were determined by chiral stationary phase HPLC analysis. See Supporting Information for experimental details. 


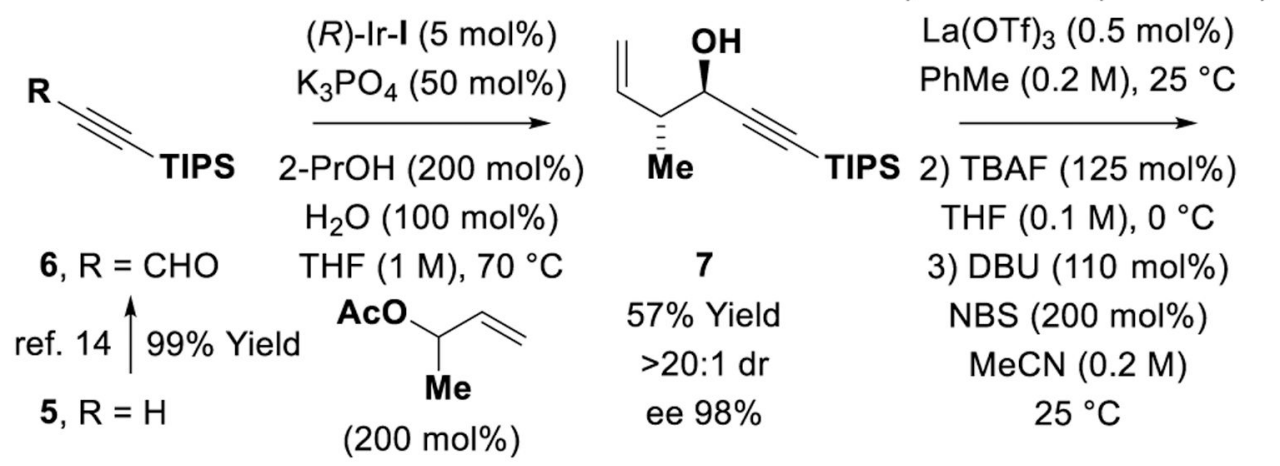

1) PMB-TCA (120 mol\%)

$\mathrm{La}(\mathrm{OTf})_{3}(0.5 \mathrm{~mol} \%)$

PhMe (0.2 M), $25^{\circ} \mathrm{C}$

TBAF (125 mol\%)

F $(0.1 \mathrm{M}), 0^{\circ} \mathrm{C}$
THF (1 M), $70^{\circ} \mathrm{C}$
$\mathrm{AcO}$
(200 mol\%)

1) $\mathrm{O}_{3}, \mathrm{MeOH}: \mathrm{Et}_{2} \mathrm{O}$

$(1: 1,0.1 \mathrm{M})$
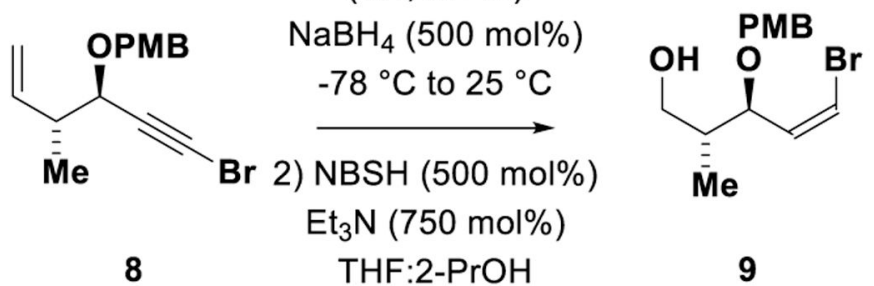

(S)-Ir-II (5 mol\%)

$\mathrm{Cs}_{2} \mathrm{CO}_{3}(100 \mathrm{~mol} \%)$

3,4-( $\left(\mathrm{NO}_{2}\right)_{2}-\mathrm{BzOH}$

(10 $\mathrm{mol} \%$ )

$\mathrm{H}_{2} \mathrm{O}(1000 \mathrm{~mol} \%)$

96\% Yield (Step 1)

$(1: 1,0.1 \mathrm{M})$

9

THF $(0.8 \mathrm{M}), 110^{\circ} \mathrm{C}$

93\% Yield (Step 2)

$25^{\circ} \mathrm{C}$

92\% Yield (Step 1)

97\% Yield (Step 2)

AcO

(200 mol\%)

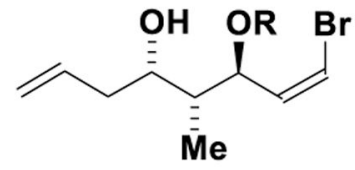

Fragment B

73\% Yield, 15:1 dr

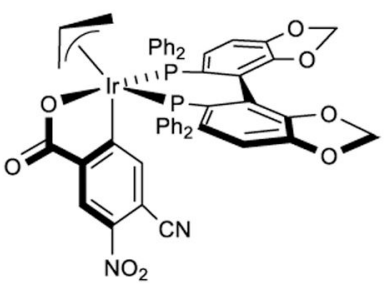

$(R)-\mid \mathrm{r}-\mathrm{I}$

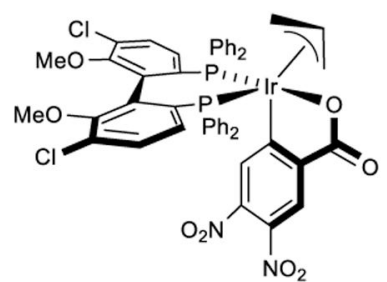

(S)-Ir-II

Scheme 2.

Preparation of Fragment $\mathbf{B}{ }^{a}$

${ }^{a}$ As described in Scheme 1. See Supporting Information for experimental details. 


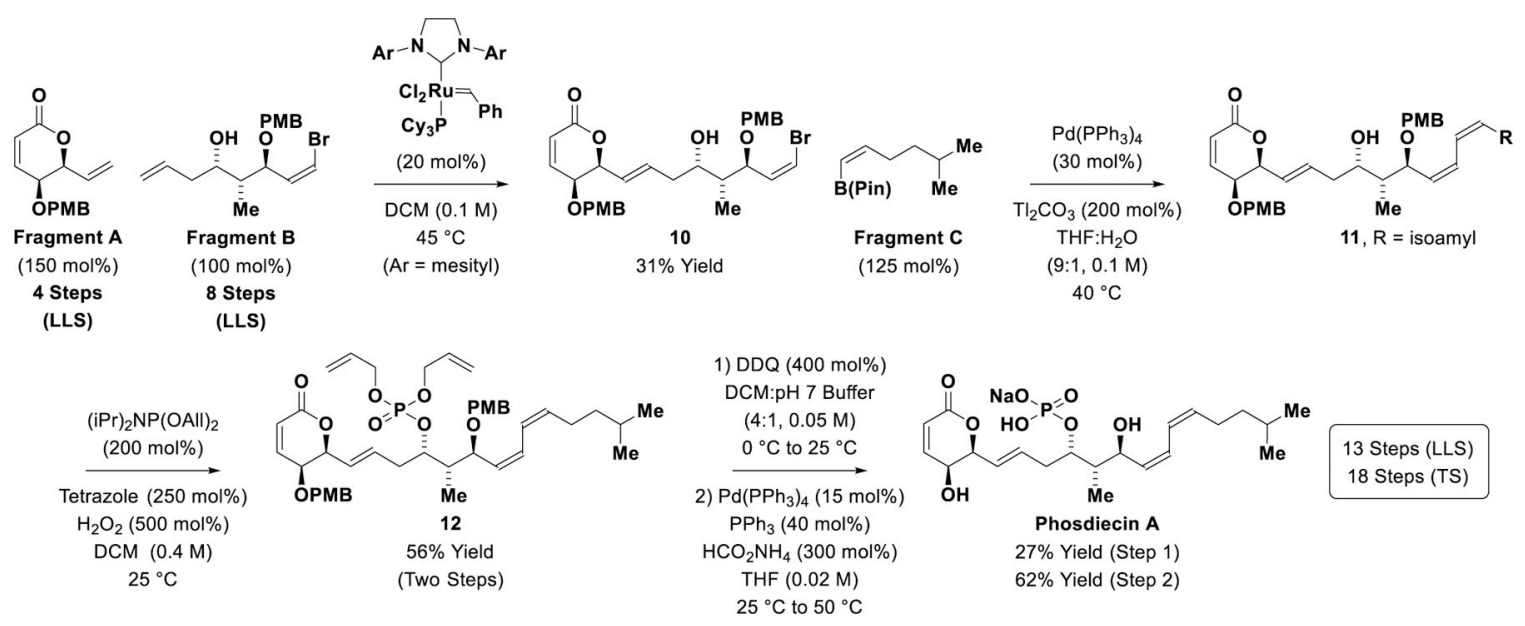

Scheme 3.

Union of Fragments $\mathbf{A}, \mathbf{B}$ and $\mathbf{C}$ and total synthesis of phosdiecin A. ${ }^{\mathrm{a}}$

aYields are of material isolated by silica gel chromatography. See Supporting Information for experimental details. 